\title{
Stereoselective Synthesis of Bicyclic Lactones Via Annelation Protocol
}

\author{
Bello Y. Makama \\ Department of Chemistry, Faculty of Science \& Science Education, Kano University of Science \& Technology. P.M.B. 3244 Wudil, Kano \\ State, Nigeria
}

\begin{abstract}
A successful two-step annelation protocol of diesters and methyl bromoacetate with 2- chlorocyclopentanone derivatives was effic iently pursued, which gave suitably substituted bicyclic lactones in high overall yields and with co mplete streoselectivity mediated by K-Selectride and Wilkinsons catalyst, is reported. As part of a program aimed at rapid synthes is of bicyclic lactones which inherently occurs in many active natural products, this paper has shown a novel and rare methods for the synthes is of these important compounds based on alkylation of cyclopentanone derivatives and further demonstrate efficient reduction protocol of these compounds to the bicyclci lactones
\end{abstract}

Keywords Annelation, Diesters, Methyl Bromo Acetate, Bicyclic Lactones

\section{Introduction}

Bicyclic lactones systems are among Nature's preferred building blocks for the construction of tricyclic lactones of varied biological activities. In particu lar, the $\gamma$-butyrolactone moiety is a recurrent feature of many naturally occurring substances examples are brasoside and littoralissone. ${ }^{1,2}$ The synthetic approaches to this bicyclic lactones have been imaginative and numerous, ${ }^{3-8}$ there is a continued demand for efficient methods for the assembling of these key compounds which give especially high levels of stereoselectivity. In this report, it is reported some of our preliminary results in the establishment of an effective methodology for the construction of these important compounds. It was envisaged that reduction of substituted cyclopentanone derivatives using methods of alkylation described by Fumihinko ${ }^{9}$ would give the ester (276). Stereocontrolled reduction with Selectride ${ }^{\circledR}$ reagents and subsequent lactonization would furn ish the cis-fus ed bicyclic ring system (278). It therefore remained to investigate the annelation of a diketone with methyl bromoacetate and later explore the cyclization protocol. The success of th is synthetic methodology would require the viability of the condensation between the cyclopentanone derivatives with the diester and methyl bromoacetate. The most important step would now be the selective Selectride ${ }^{\circledR}$ mediated reduction of the ketone in co mpounds (276) and (283) to give the $s y n$-alcohols which could readily ring closed into the

* Corresponding author:

makamabel@yahoo.com (Bello Y. Makama)

Published online at http://journal.sapub.org/ajoc

Copyright (C) 2012 Scientific \& Academic Publishing. All Rights Reserved desired bicyclic structures.

\section{Results \& Discussion}

\subsection{Expl oration of Direct For mation of Dimethy 2-(2-Oxocyclopentyl) Malonate}

Following a report by Fumih inko ${ }^{9}$ that 2 -chlorocyclopen tanone (275) can be converted into dimethyl 2-(2-oxocyclopentyl) malonate (276) we obtained the corresponding diester (276) in 53\% yield. The $1 \mathrm{H}$ NMR spectrum fully supported the proposed structure (276), displaying a doublet centred at $\delta 3.84 \mathrm{ppm}(\mathrm{J} 5.8 \mathrm{~Hz}$ ) corresponding to a methine proton bonded to the diester, a pair of three proton singlets at $\delta 3.78 \mathrm{ppm}$ and at $\delta 3.73 \mathrm{ppm}$ for methyl esters and a one proton resonance at $\delta$ 2.97-2.88 ppm for the meth ine adjacent to the ketone. The presence of the ester groups and the ketone was manifested in the IR spectrum, with characteristic absorptions at, $1738 \mathrm{~cm}^{-1}$ and $1749 \mathrm{~cm}-1$ respectively. The mass spectrum fully supported this with a molecular ion of $\mathrm{m} / \mathrm{z} 214$ Scheme 1.1 .<smiles>CC1CCCC1=O</smiles>

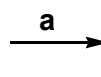

(275)<smiles>COC(=O)[C@H](C(C)=O)C1CCCC1=O</smiles>

(276)
Scheme 1.1. (a) dimethyl malonate, DMF/THF (1:1), NaH, 53\%

The reduction of the ketone in (276) by treatment with 1.2 equiv of sodium borohydride at $0^{\circ} \mathrm{C}$ furnished a mixture of two products which were chromatographically separable. 
The major compound turned out to be (277) with the ketone group having been reduced, and having a distinct broad absorption in the IR spectrum at $3504 \mathrm{~cm}^{-1}$ corresponding to the hydroxyl group. The $1 \mathrm{H}$ NMR spectrum showed a one proton resonance at $\delta 3.96-3.91 \mathrm{ppm}$ due the methine proton adjacent to the hydroxyl bearing carbon and two three proton singlets at $\delta 3.68 \mathrm{ppm}$ and $\delta 3.67 \mathrm{ppm}$ for the two methoxy groups. The C-2 proton appeared at $\delta 3.32 \mathrm{ppm}$ with a coupling constant of $7.8 \mathrm{~Hz}$, which lent support to the cis configuration of this predominant product at C-6 and C-2. The minor product (278) turned out to be the desired lactone, obtained in a totaly ield of $26 \%$. The IR spectrum displayed a characteristic band at $1742 \mathrm{~cm}^{-1}$, that strongly supported the presence of a $\gamma$-lactone and absorption at $1733 \mathrm{~cm}^{-1}$ for the acyclic ester. The $1 \mathrm{H}$ NMR spectrum had a triplet at $\delta 5.06$ ppm due to the C-7 methine proton with a coupling constant of $(5.3 \mathrm{~Hz})$ and a singlet at $\delta 3.73 \mathrm{ppm}$ associated with the methoxy ester protons. The cis configuration between the C-2 and C-6 was fully confirmed due to a doublet at $\delta 3.68$ $\mathrm{ppm}$ indicative of the proton adjacent to the ester with a characteristic cis coupling of $(3.3 \mathrm{~Hz})$. The mo lecular ion of $\mathrm{m} / \mathrm{z} 184$ for the compound was also in accord with structure (278) Scheme 1.2.

In our attempt to improve the selectivity syn-alcohol which readily cyclizes to (278), sterically bulky reagents were considered as suitable reagents. It was decided to examine the reduction $\mathrm{L}$ and $\mathrm{K}$-Selectrides ${ }^{\circledR} .^{10-12}$ It was envisaged that reduction with these reagents, which are very bulky and have low coordinating ability, could follow the model of Felkin and Anh. ${ }^{13}$ This plan finally rewarded us with success because as it was hoped, the Selectride reagents produced syn-alcohol selectivity under all conditions studied, the steroselectivity was found to increased with decreasing temperature to produce the diastereoisomers (277) and (278). The highest selectivity was achieved with K-Selectride ${ }^{\circledR}$ at $-78^{\circ} \mathrm{C}\left(100 \%\right.$ syn-selectivity) and L-Selectride ${ }^{\circledR}$ (99:1 syn-selectivity) Table 1.1 .

When (278) was subjected to further purification on column chro matography eluting with hexane : ethyl acetate, a number of spots began to show in the TLC analysis, indicating decomposition of the lactone. Two products could be separated and identified from the complex mixture. The major product was the desired lactone, (278), but the decarboxylated compound (279) was also produced. The decarboxylated product (279) exhibited an absorption in the IR spectrum at $1769 \mathrm{~cm}^{-1}$ which is expected of the $\gamma$-lactone (279). The ${ }^{1} \mathrm{H}$ NMR spectrum included a one proton triplet at $\delta 5.02 \mathrm{ppm}(J 5.0 \mathrm{~Hz})$ accounting for methine adjacent to the oxygen in the $\gamma$-lactone, and a combination of a mu ltip let and a doublet at $\delta 2.97-2.80 \mathrm{ppm}$ and at $\delta 2.79 \mathrm{ppm}$ accounting for the diastereotopic $\mathrm{CH}_{2}$ adjacent to the lactone carbonyl group. The absence of the exocyclic methyl ester protons was evident. These data, combined with a mo lecular ion of $\mathrm{m} / \mathrm{z} 126$, led us to conclude that the decarboxylation had occurred to produce the lactone (279) Scheme 1.3.

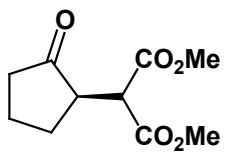

(276)

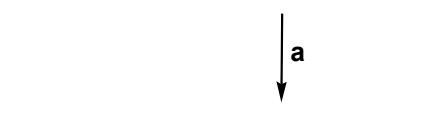

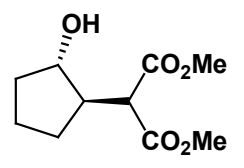

(277), 65\%

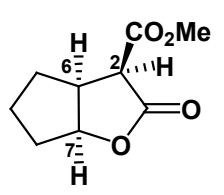

(278), $26 \%$
Scheme 1.2. (a) ethanol, $\mathrm{NaBH}_{4}, 0^{\circ} \mathrm{C}, 30 \mathrm{~min}$

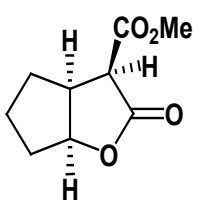

(278)

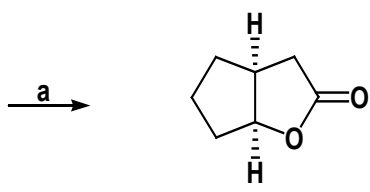

(279)
Scheme 1.3. (a) silica gel, hex : ethyl acetate (1:3), 32\%

Table 1.1. Stereoselectivity of reduction of (278)

\begin{tabular}{llc}
\hline & & \\
Reagents & Temp. $\left({ }^{\circ} \mathrm{C}\right)$ & syn $-(\mathbf{2 7 8})$ : anti (277) \\
\hline \multirow{2}{*}{$\mathrm{NaBH}_{4}$} & $\mathrm{RT}$ & $44: 56$ \\
& $0{ }^{\circ} \mathrm{C}$ & $35: 65$ \\
& $-78^{\circ} \mathrm{C}$ & $29: 71$ \\
& $\mathrm{RT}$ & $79: 21$ \\
& $0{ }^{\circ} \mathrm{C}$ & $98: 8$ \\
& $-78^{\circ} \mathrm{C}$ & $100: 0$ \\
& $\mathrm{RT}$ & $73: 27$ \\
& ${ }^{\circ}-{ }^{\circ} \mathrm{C}$ & $91: 9$ \\
& $-78^{\circ} \mathrm{C}$ & $99: 1$ \\
\hline
\end{tabular}


<smiles>O=C1CCC(=O)C1</smiles>
$\stackrel{a}{\cdots \rightarrow}$

(280)

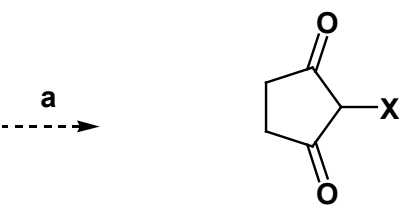

(281)
Scheme 1.4. (a) NBS, NCS, $\mathrm{KIO}_{3}$, THF

Attempts to introduce functionality at C-2 of compound (280) by direct halogenation with either NBS or NCS were to no avail, and unchanged starting material was recovered, in some cases the reaction yielded compounds which could not be characterised. Attempted direct iodination of compound (280) by treatment with $\mathrm{KIO}_{3}$ was likewise unsuccessful Scheme 1.4.

The approach at this juncture was to capitalise on the propensity of methyl bromacetate to react cyclopentene-1,3dione (282). Fortunately, ester (283) could be derived from cyclopentene-1,3-dione (282) in excellent yield. A modification of Fumihin ko's conditions $\left(\mathrm{CH}_{3} \mathrm{CN}\right.$, THF and methyl boromoacetate) with cyclopententene-1,3-dione (282), afforded ester (283) in an isolable yield of $78 \%$. The $1 \mathrm{H}$ NMR spectrum of the ester (283) was diagonistic, with the methylene protons adjacent to the ester appearing as a singlet at $\delta 4.61 \mathrm{ppm}$, the three methyl ester protons appearing as a singlet at $\delta 3.38 \mathrm{ppm}$ and a two proton triplet centred at $\delta 2.72 \mathrm{ppm}$. For methylene bonded to the ketone and the methylene adjacent to the enol hydroxyl, two protons were shown as a triplet centred at $\delta 2.49 \mathrm{ppm}$. Furthermore, the presence of the enol hydroxyl was manifested by a characteristic absorption at $3389 \mathrm{~cm}^{-1}$ in the IR spectrum. When the ester (283) was subjected to the conditions developed for cyclisation, namely, acidify ing the mixture to $\mathrm{pH} 2$ and stirring at room temperature, TLC analysis indicated a new product had been formed, However, after aqueous work up, ${ }^{1} \mathrm{H}$ NMR analys is showed no reaction has taken place and only starting material had been recovered Scheme 1.5.<smiles>O=C1CCC(=O)C1</smiles>

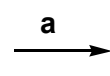

(282)

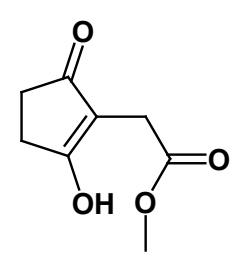

(283)
Scheme 1.5. (a) $\mathrm{MBA}, \mathrm{Et}_{3} \mathrm{~N}, \mathrm{CH}_{3} \mathrm{CN}, \mathrm{pH} 2,78 \%$

Efforts to saturate the ring using $\mathrm{PtO}_{2}$ or $\mathrm{Pd}-\mathrm{C}$, however, only met with failure. One may suppose, based on the structure of (283), that the steric hindrance in the vicinity of the olefinic bond is responsible for the lack of success with the hydrogenation protocol. However attempt to reduce the ketone in (283) using Wilkinson catalyst in catecholborane proved to be successful ${ }^{14}$, followed by attempts to cyclize the product using the conditions developed for cyclization, namely, acidifying the mixture to $\mathrm{pH} 2$ and stirring at room temperature, produced the bicyclic lactone (284) Scheme 1.6

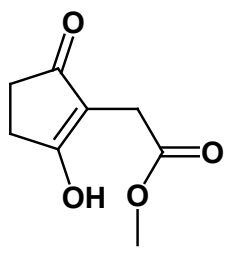

(283)
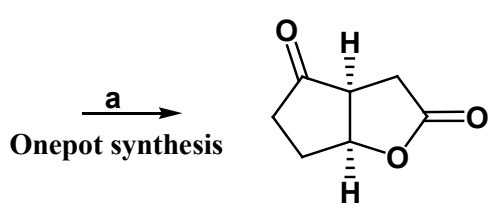

(284)
Scheme 1.6. (a) Wilkinsons Cat alyst, Cat echolborane, aq. $\mathrm{HCl}, \mathrm{pH} 2,73 \%$

\section{Experimental Techniques}

Commercial reagents were obtained from Aldrich and Lancaster chemical suppliers and were used directly as supplied or purified prior to use following the guidelines of Perrin and Amarego.15 Dichloromethane and acetonitrile were refluxed over and distilled from $\mathrm{CaH}_{2}$ prior to use. Diethyl ether and ethanol were obtained dry from Aldrich. THF was dried by distillation from the sodium benzophenone ketyl rad ical under nitrogen. Light petroleum is the fraction of petroleum ether boiling in the range $30-40^{\circ} \mathrm{C}$, and it was fractionally distilled through a $36 \mathrm{~cm}$ Vigreux column before use. Non-aqueous reagents were transferred under argon via syringe. Organic solutions were concentrated under reduced pressure on a Büchi rotary evaporator using a water bath. Thin-layer chromatography (TLC) was performed on Merck aluminium-backed plates coated with $0.2 \mathrm{~mm}$ silica gel 60 -F plates. Visualization of the developed chromatogram was performed by UV fluorescence quenching at $254 \mathrm{~nm}$, or by staining with a KMnO4 solution. 1H and 13C NMR spectra were recorded on a Bruker DPX250 (250 M Hz for protons) and a Brüker AMX400 (400 MHz for protons). Data for ${ }^{1} \mathrm{H}$ NMR are reported as follows: chemical shift $(\delta$-ppm), multiplic ity $(\mathrm{s}=$ singlet, $\mathrm{d}=$ doublet, $\mathrm{t}=$ trip let, $\mathrm{q}=$ quartet, $\mathrm{m}=$ mult iplet), integration, coupling constant in (Hz). Data for 13C NMR spectra are reported in terms of chemical shift (ppm) down field from TMS. IR spectra were recorded on a Perkin Elmer Paragon 1000 or a Perkin Elmer 881 spectrometer as a thin film between sodium chloride plates or as a $\mathrm{KBr}$ disk. All absorptions are reported in terms of frequency of absorption $\left(\mathrm{cm}^{-1}\right)$. Mass spectrometric data were recorded on VG Autospec, under conditions of chemical ionisation (C.I) using ammonia as the ionising source. Peaks are quoted in the form $(\mathrm{m} / \mathrm{z})$ (relative intensity).

\subsection{Experimental Procedures}

Dime thyl 2-(2-oxocycl opentyl)mal on ate (276)

To a stirred solution of $\mathrm{NaH} \quad(209 \mathrm{mg}, 5.49 \mathrm{mmol}, 1.30$ equiv $)$ in THF-DMF $(10 \mathrm{~mL}, 1: 1)$ at $0^{\circ} \mathrm{C}$ was added dimethyl 
malonate (724 mg, $5.49 \mathrm{mmol}, 1.3$ equiv) and the solution was stirred for $30 \mathrm{~min}$ at room temperature. 2-chlo rocyclopentanone (275) (500 $\mathrm{mg}, 4.22 \mathrm{mmol}, 1.00$ equiv) was added to the solution and then further stirred at room temperature for $8 \mathrm{~h}$, by which time TLC analysis, revealed the formation of a new product. Saturated aqueous $\mathrm{NH} 4 \mathrm{Cl}$ solution $(10 \mathrm{~mL})$ was added to the mixture and the organic layer was extracted with ether (4 x $15 \mathrm{~mL})$. The combined organic layers were washed with sat. $\mathrm{NaHCO}_{3}$ solution ( 4 x10 mL), brine $(4 \times 10 \mathrm{~mL})$, dried over $\mathrm{MgSO}_{4}$ and concentrated in vacuo. The residue was purified by column chromatography on silica gel using a gradient of solvents, hexane: ethylacetate from $(5: 1-100 \%$ ethylacetate) to afford the title compound as a colourless oil (192 mg, $53 \%$ ); vmax (thin film $\left./ \mathrm{cm}^{-1}\right), 2961,1749,1738 ; \delta \mathrm{H}(250$ $\mathrm{MHz}, \mathrm{CDCl} 3) 3.84$ (1H, d, J $5.8 \mathrm{~Hz}, \mathrm{CH}(\mathrm{CO} 2 \mathrm{CH} 3) 2), 3.78$ (3H, s, CH3), 3.73 (3H, s, CH3), 2.97-2.88 (1H, m, CHC=O), 2.56-1.99 (4H, m, CH2CH, $\mathrm{CH} 2 \mathrm{C}=\mathrm{O}), 2.00-1.81(2 \mathrm{H}, \mathrm{m}$, $\mathrm{CH} 2 \mathrm{CH} 2 \mathrm{C}=\mathrm{O}) ; \delta \mathrm{C}(62.5 \mathrm{MHz}, \mathrm{CDCl}), 216.2,169.1,168.6$, 53.9, 51.6, 51.2, 41.2, 38.2, $23.820 .8 ; \mathrm{m} / \mathrm{z}$ (C.I) $215\left(\mathrm{MH}^{+}\right.$, $100 \%), 214(4 \%), 183(11 \%), 155(7 \%), 123 \quad(3 \%)$, $\mathrm{C} 10 \mathrm{H} 15 \mathrm{O} 5$, requires 215.092 , found , 215.0913

\section{Dime thyl -2,2-hydr oxycyclopentyl)malonate (277) \\ Meth yl-2-oxo-he xah ydr o-2 H-c yclopen ta [b]fur an-3-ca rboxyl ate (278) \\ To a stirred solution of dimethyl 2-(2-o xocyclopentyl)ma} lonate (276) (80 mg, $0.37 \mathrm{mmol}$, and 1.00 equiv) in ethanol $(7 \mathrm{~mL})$ in an Erlenmeyer flask was added $\mathrm{NaBH}_{4}$ at room temperature ( $16.8 \mathrm{mg}, 0.44 \mathrm{mmol}, 1.20$ equiv) in small portions over a period of $15 \mathrm{~min}$ The reaction mixture was stirred for further 30 minutes and then poured into water ( 5 $\mathrm{mL}$ ). (5\%) dilute hydrochloric acid (4 drops) was added and the organic layer was extracted with ether $(2 \times 10 \mathrm{~mL})$, dried over $\mathrm{MgSO}_{4}$ and concentrated in vacuo. Column chromatography on silica, eluting with hexane : ether $(3: 1)$ afforded (277) as a colourless oil (66 mg, 65\%); vmax (thin film/cm-1), 3504, 2955, 2255, 1731; $\delta \mathrm{H}(250 \mathrm{MHz}, \mathrm{CDCl} 3)$ 3.96-3.91 (1H, m, CHOH), $3.68(3 \mathrm{H}, \mathrm{s}, \mathrm{CH} 3), 3.67$ (3H, s, CH3), 3.32 (1H, d, J $7.8 \mathrm{~Hz}, \mathrm{CH}(\mathrm{CO} 2 \mathrm{Me}) 2), 2.33-2.28(1 \mathrm{H}$, $\mathrm{m}, \mathrm{CH}), 1.88-1.83$ (2H, m, CH2), 1.63-1.53 (3H, m, CH2), 1.28-1.25 (1H, m, CH2); $\delta \mathrm{C}(62.5 \mathrm{MHz}, \mathrm{CDCl} 3) 169.2$, $168.6,76.2,55.9,51.5,51.0,46.8,33.4,28.3,21.3 ; \mathrm{m} / \mathrm{z}$ (C.I) $216(\mathrm{MH}+, 9 \%), 159$ (10\%), 150 (4\%), C10H17O5, requires 216.0998, found, 216.0935; further elution yielded (278) (18 mg, 26\%); vmax (thin film/cm-1), 2957, 1742, 1733, ; $\delta \mathrm{H}(250 \mathrm{MHz}, \mathrm{CDCl3}) 5.06(1 \mathrm{H} \mathrm{t}, \mathrm{J} 5.3 \mathrm{~Hz}, \mathrm{CHO})$, $3.73(3 \mathrm{H}, \mathrm{s}, \mathrm{CO} 2 \mathrm{CH} 3), 3.68(1 \mathrm{H}, \mathrm{d}, \mathrm{J} 3.3, \mathrm{CHC}=\mathrm{O})$, 3.14-3.10 (1H, m, $\mathrm{CHCHC}=\mathrm{O}), 1.98-1.56(6 \mathrm{H}, \mathrm{m}, \mathrm{CH} 2)$; $\delta \mathrm{C}(62.5 \mathrm{MHz}, \mathrm{CDC13}) 176.9,168.5,86.5,54.8,53.7,43.5$, 33.5, 32.9, 23.9; $\mathrm{m} / \mathrm{z}$ (C.I) $185(\mathrm{MH}+, 45 \%), 141(51 \%)$, $134(43 \%), 124(67), 101$ (77\%) 84 (54\%) C9H13O4, requires 185.0814 , found, 185.0806

Hexahydr ocyclopenta[b]furan-2-one (279) Methyl-2-o xo -he xahydro-2H-cyclopenta[b]furan-3-carbo xy late (278) (50 mg, $0.27 \mathrm{mmol}, 1.00$ equiv) was subjected to column chro matography on silica eluting Hex : ethyl acetate $(1: 3)$ to afford the title compound (279) as a colourless oil
(11 mg, 32\%); vmax (thin film/ $\mathrm{cm}^{-1}$ ), 2962, 2879, 1769, 1205, 982; $\delta \mathrm{H}(250 \mathrm{MHz}, \mathrm{CDCl} 3) 5.02$ ( $1 \mathrm{H} \mathrm{t}, \mathrm{J} 5.0 \mathrm{~Hz}$, $\mathrm{CHO}), 2.97-2.80(1 \mathrm{H}, \mathrm{m}, \mathrm{CH} 2 \mathrm{COO}), 2.79$ (1H, d, J $10 \mathrm{~Hz}$, $\mathrm{CH} 2 \mathrm{COO}$ ), 2.28-2.15 (1H, m, CHCHO), 2.09-2.02 (1H, m, $\mathrm{CH} 2), 1.97-1.80(5 \mathrm{H}, \mathrm{m}, \mathrm{CH} 2) ; \delta \mathrm{C}(62.5 \mathrm{MHz}, \mathrm{CDCl} 3)$ 177.2, 86.6, 37.8, 36.0, 33.5, 29.9, 23.4; m/z (C.I) 125 (MH-, 56\%), 124 (58\%), 109 (8\%), 124 (58), 109 (8\%) $107(9 \%)$ $\mathrm{C} 7 \mathrm{H} 11 \mathrm{O} 2$, requires 125.0603 , found, 125.062

Meth yl 2-(2-hyd roxy-5-oxocy clop ent-1-en yl)aceta te (283)

To a stirred solution of 1,3-cyclopentanedione (279) (5 g, $0.05 \mathrm{mmol}, 1.00$ equiv) in acetonitrile $(80 \mathrm{~mL})$ at $0^{\circ} \mathrm{C}$ was added triethylamine ( $7.6 \mathrm{~g}, 0.07 \mathrm{mmol}, 1.30$ equiv), and the solution was stirred for $10 \mathrm{~min}$ at roo m temperature. Methyl bromoacetate ( $9.9 \mathrm{~g}, 0.07 \mathrm{mmol}, 1.30$ equiv) was then added and stirring was continued over night by which time TLC revealed a new spot. Saturated aqueous $\mathrm{NH} 4 \mathrm{Cl}$ solution (15 $\mathrm{mL}$ ) was added to the mixture and the organic layer was extracted with ethyl acetate $(3 \times 20 \mathrm{~mL})$. The combined organic layers were washed with sat. $\mathrm{NaHCO}_{3}$ solution (2 x15 mL), brine ( $2 \times 15 \mathrm{~mL})$, dried over $\mathrm{MgSO}_{4}$ and concentrated in vacuo. The residue was purified by column chromatography on silica gel using a solvent gradient hexane : ethyl acetate from (4:1) to afford the title compound as a white powder $(6.6 \mathrm{~g}, 78 \%)$; m.p. $\left(148-151^{\circ} \mathrm{C}\right)$; vmax (KBR/cm-1), 3389, 2927, 1726, 1656, 1574; $\delta \mathrm{H}(250 \mathrm{MHz}$, $\mathrm{CDCl} 3) 4.61$ (2H, s, CH2CO2CH3), $3.38(3 \mathrm{H}, \mathrm{s}, \mathrm{COOCH} 3)$, $2.72(2 \mathrm{H}, \mathrm{t}, \mathrm{J} 2.5 \mathrm{~Hz}, \mathrm{CH} 2 \mathrm{C}=\mathrm{O}), 2.49(2 \mathrm{H}, \mathrm{t}, \mathrm{J} 2.5 \mathrm{~Hz}$, $\mathrm{CH} 2 \mathrm{COH}) ; \delta \mathrm{C}(62.5 \mathrm{MHz}, \mathrm{CDCl} 3) 205.8,189.4,167.5$, $106.7,67.9,53.1,34.8,28.6 ; \mathrm{m} / \mathrm{z}$ (C.I) $171(\mathrm{MH}+, 100 \%)$, 170 (10\%), $142(14 \%), 131(5 \%), 81$ (2\%) C8H11O4, requires 171.0657 , found, 171.0657

Tetr ahydr o-cyclopenta[b] fur an-2,4-di one (284)

To a stirred solution of Wilkinsons catalyst $\left(\mathrm{RhPPh}_{3} \mathrm{Cl}\right)$ (236.00 mg, $0.589 \mathrm{mmol}, 0.5$ equiv) in anhydrous THF (7 $\mathrm{mL}$ ) under $\mathrm{N} 2$ cooled to $-20 \mathrm{oC}$ was added to methyl 2-(2-hydroxy-5-o xocyclopent-1-enyl)acetate (283) (200.0 $\mathrm{mg}, 1.18 \mathrm{mmol}, 1.00$ equiv), followed by the addition of catecholborane (424.45 mg, $3.54 \mathrm{mmol}, 3.0$ equiv). The reaction was allowed to stir for $24 \mathrm{hr}$, by which time TLC analys is revealed a new product been formed. The reaction was quenched by the addition phosphate buffer $\mathrm{pH} 7.00$, (4 $\mathrm{mL})$. The product was extracted with ether $(4 \times 10 \mathrm{~mL})$, washed with $10 \%$ aqueous sodium sulfite $(2 \times 5 \mathrm{~mL})$ and saturated sodium carbonate $(4 \times 5 \mathrm{~mL})$. The ether layer was followed by the addition of dilute hydrochloric acid (5\%) at 0 ${ }^{\circ} \mathrm{C}$ until the $\mathrm{pH} 2$ was reached, by which time, TLC analys is showed a new product has been formed. The aqueous layer was extracted with ether $(4 \times 10 \mathrm{~mL})$, the extract dried over $\mathrm{MgSO}_{4}$ and concentrated in vacuo. Column chro matography on silica, eluting with hexane : ethyl acetate gave the product as a colourless oil $(122 \mathrm{mg}, 73 \%)$; vmax (thin film $\left./ \mathrm{cm}^{-1}\right)$, 2929, 2851, 1751, 1737, 1644, 1088; $\delta \mathrm{H}(250 \mathrm{MHz}, \mathrm{CDCl} 3)$ 5.24 (1H, t, J 5.0 Hz, CHO), 2.96 (1H, dddd, J 5.0 Hz, J 2.5 $\mathrm{Hz}, \mathrm{CH}=\mathrm{CH} 2 \mathrm{C}=\mathrm{O}), 2.85(1 \mathrm{H}, \mathrm{d}, \mathrm{J} 10 \mathrm{~Hz}, \mathrm{~J} 2.5 \mathrm{~Hz}$, $\mathrm{CH} 2 \mathrm{C}=\mathrm{O}), 2.78(1 \mathrm{H}, \mathrm{d}, \mathrm{J} 15.0 \mathrm{~Hz}, \mathrm{CH} 2 \mathrm{C}=\mathrm{O}), 2.57-2.43(3 \mathrm{H}$, $\mathrm{m}, \mathrm{CH} 2 \mathrm{CHO}, \mathrm{CH} 2 \mathrm{C}=\mathrm{O}), 2.32-2.22(1 \mathrm{H}, \mathrm{m}, \mathrm{CH} 2 \mathrm{CHO}) ; \delta \mathrm{C}$ (62.5 MHz, CDCl3) 209, 176.6, 82.6, 77.6, 48.0, 35.0, 32.8, 
27.3; m/z (C.I) $141(\mathrm{MH}+, 90 \%), 130$ ( 61\%), $132(100 \%)$, 112 (21\%), 99 (11\%) C7H10O3 requires 141.0809 , found, 141.0549 .

\section{Conclusions}

In this paper we have shown an expeditious approach to the synthes is of bicylcic lactone using stereocontrol bulky reagents such as $\mathrm{K}$ selectride and L-Selectride. These two reagents proved successful in deriving the readily desired syn-alcohol selectivities which cyclis es to furnish the desired lactones in average good yields. We have also shown the versatility of Wilkinson's catalyst in a one-pot synthes is of lactones

\section{REFERENCES}

[1] Macmillan, D. W. C.; Mangion, I. K. Total Synthesis of Brasoside and Littoralisone. Journal of the American Chemical Society 2005, 127, 3697.

[2] Ishibashi, M.; Kimihoro, M.; Li, Y. S.; Ohizumi, Y. Littoralisone, a Novel Neuritogenic Iridolactone Having an Unprecedented Heptacyclic Skeleton Including Four- and Nine-Membered Rings Consisting of Glucose from Verbena littoralis. Journal of Organ ic Chemistry, 2001, 66, 2165.

[3] Maulide, N. \& Marko, I. E. Stereoselective synthesis of bicyclic lactones by annelation with functionalised orthoesters. Chem. Commun., 2006, 1200.

[4] Madhushaw, R. J.; Li, C. L.; Shen, K. H.; Hu, C. C.; Liu, R. S. Tungsten-promoted [3+2]- and [3+3]-cycloaddition of epoxides with alkynes. A facile enantiospecific synthesis of bicy clic lactones. Journal of the American Chemical Society, $2001,123,7427$.

[5] Burton, J. W.; Anderson E. A.; O'Sullivan, P. T.; Collins, I.; Davies J. E.; Bond, A. D.; Feeder, N.; Holmes, A. B. The Claisen rearrangement approach to fused bicyclic medium-ring oxacy cles. Biomol Chem., 2008 6, 693.
[6] Gang, L.; Morgan E. S.; Daniel R. A.; Diastereoselective, Nucleophile-Promoted Aldol-Lactonization of Ketoacids Leading to Bicyclic- $\beta$-Lactones. Journal of Organic Chemistry, 2012, 772496.

[7] Makama, B. Y. Preparation of Bicy clic Lactone using Lewis Acids Catalyzed Ene-Reaction; Science World Journal, $2010,5,15$.

[8] Martin, J. S.; Christopher, M. B.; Nathan, E. G.; Stephen, M. C.; Nicholas, L. U.; Breanne, D. W. K.; Christine S.; Larry E. O. Divergent Synthesis and Chemical Reactivity of Bicyclic Lactone Fragments of Complex Rearranged Spongian Diterpenes. Journal of the American Chemical Society, 2011, $133,17494$.

[9] Fumihinko, S. ; Miwaki, M.; Kumio, O.; Synthesis and X-ray crystal structures of tricyclic ketone containing trans-fused bicyclo[3.3.0] octane unit. Tetrahedron, 1995, 51, 4439.

[10] Makama, B. Y. Synthetic Approach to an Enantio-Enriched Tricy clic Core in Brasoside; Science World Journal, 2010, 5, 26.

[11] Arun, K. G.; Jorden K.; David, D. A.; Xiaoming, X.; Christine, M.; Departments of Chemistry and Medicinal Chemistry, Purdue University, West Lafayette, IN 47907 Email: akghosh@purdue.edu L-Selectride-Mediated Highly Diastereoselective Asymmetric Reductive Aldol Reaction: Access to an Important Subunit for Bioactive Molecules. Org Lett., 2008, 10, 4811.

[12] Robertson, J., William, P. U.; Scott, G. L.; Aspects of Stereocontrol in the L-Selectride reduction of 4-acyl-1,3-diox alane derivatives. Tetrahedron, 2010, 66, 2363.

[13] Anh, N. T.; Eisenstein, O.; Lefour, J. M. Orbital factors and asymmetric induction. Journal of the American Chemical Society, 1973, 95, 6146.

[14] David A. E.; Amir H. H., Reduction of \&Hydroxy Ketones with Catecholborane. A Stereoselective Approach to the Synthesis of Syn 1,3-Diols. Journal of Organic Chemistry, 1990, 55, 5191 .

[15] Perrin, D. D.; Amarego, W. L. F. Purification of Laboratory Chemicals, Pergamon Press Oxford, 1998. 